FOLIA POMERANAE UNIVERSITATIS TECHNOLOGIAE STETINENSIS

Folia Pomer. Univ. Technol. Stetin., Oeconomica 2018, 346(92)3, 55-68

Arkadiusz NIEDZIÓŁKA

\title{
STRATEGICZNE ASPEKTY ZRÓWNOWAŻONEGO ROZWOJU AGROTURYSTYKI W MAŁOPOLSCE
}

\author{
STRATEGIC ASPECTS OF THE SUSTAINABLE DEVELOPMENT \\ OF AGRITOURISM IN MAŁOPOLSKA
}

Instytut Nauk Humanistyczno-Społecznych i Turystyki, Podhalańska Państwowa Wyższa Szkoła Zawodowa w Nowym Targu, ul. Kokoszków 71, 34-400 Nowy Targ, ORCID: 0000-0003-2546-41 e-mail: a.niedziol@gmail.com

\begin{abstract}
Summary. In the article, the issues related to the sustainable development of agritourism and the strategy of its development were included. The concept of sustainable development and its references to tourism have been described on the basis of literature. The book items and scientific articles related to the development strategy of agritourism services in the contex of sustainable development have been reviewed. The issue has been presented on the example on the development strategies of the communes in two counties in Malopolska characterized by the largest number of agritourism farms: Nowy Targ County and Tatra County. The document research method was used for this. The strategies of all communes belonging to these counties were analyzed. An analysis of the results of questionnaire surveys carried out in municipal offices was presented, too. These studies concerned the agritourism development strategy in the commune on the principles of sustainable development. In all strategies, the most important factors for the sustainable development of agritourism were natural values.
\end{abstract}

Słowa kluczowe: agroturystyka, rozwój zrównoważony, strategia.

Key words: agritourism, sustainable development, strategy.

\section{WSTĘP}

W artykule zaprezentowano problematykę strategii rozwoju agroturystyki opisaną w literaturze w okresie przed wejściem Polski do Unii Europejskiej oraz po nim. Przedstawiono różne strategie rozwoju usług agroturystycznych, koncentrując się głównie na koncepcji rozwoju zrównoważonego.

Agroturystyka zaczęła rozwijać się w Polsce na początku lat 90 ubiegłego stulecia. W różnych częściach kraju rolnicy zajęli się wynajmowaniem pokoi gościnnych dla turystów, traktując zarobki z usług agroturystycznych jako dodatkowe bądź alternatywne źródło dochodów, oprócz działalności rolniczej. Profity finansowe z działalności agroturystycznej nierzadko przekraczały dochody z gospodarstwa rolnego. Dotyczyło to przeważnie regionów charakteryzujących się wybitnymi walorami przyrodniczymi, górami, rzekami, jeziorami, gęstymi lasami; są to obszary cenne pod względem przyrodniczym, a niekiedy podlegające ustawowej ochronie.

W strategiach rozwoju licznych gmin wiejskich i miejsko-wiejskich w Polsce, szczególnie w rejonach atrakcyjnych turystycznie, znalazły się działania wspierające rozwój usług agroturystycznych. W analizach SWOT zawartych w strategiach, w silnych stronach gminy 
oraz w szansach ich rozwoju w przyszłości, często zwracano uwagę na różne czynniki determinujące rozwój turystyki wiejskiej i agroturystyki, m.in. na walory krajobrazowe wspomnianych obszarów cennych przyrodniczo, takich jak regiony pojezierne, górskie, tereny obfitujące w kompleksy leśne. Pisano również o walorach kulturowych, zabytkach architektury, folklorze, bogatym dziedzictwie kulturowo-historycznym. Stawiano w strategiach na rozwój agroturystyki w kontekście tzw. rozwoju zrównoważonego dotyczącego poszanowania dóbr przyrodniczych i antropogenicznych, w tym odrębności kulturowej. Agroturystykę przeciwstawiano turystyce masowej oraz zwracano uwagę na potrzebę odpowiedniego zachowania turystów.

W ostatnich kilkunastu latach $X X$ wieku w literaturze polskiej poświęcono wiele miejsca zagadnieniom związanym z koncepcją rozwoju zrównoważonego (Leszczycki i Domański 1992; Kozłowski 1994; Fiedor 1999). W większości jego definicji zwracano uwagę na rozwój społeczny i gospodarczy zgodny z uwarunkowaniami przyrodniczymi. Podkreślano potrzebę ochrony środowiska przyrodniczego nie tylko w odniesieniu do obszarów chronionych (takich jak parki narodowe, parki krajobrazowe, rezerwaty przyrody), ale w ogóle do obszarów atrakcyjnych przyrodniczo, jednak ustawowo niepodlegających ochronie. W późniejszym okresie, już po przystąpieniu Polski do Unii Europejskiej (1 maja 2004 r.), w polskiej literaturze naukowej również liczne publikacje nawiązywały do koncepcji rozwoju zrównoważonego, odnoszącej się głównie do potrzeby zachowania i ochrony zasobów środowiska przyrodniczego i kulturowego.

W ostatnich kilkunastu latach XX stulecia w literaturze pojawiły się także koncepcje rozwoju zrównoważonego w odniesieniu do turystyki. Pojawił się termin „turystyka zrównoważona” oraz inne bliskoznaczne i pokrewne jemu pojęcia związane z formami turystyki, np. turystyka alternatywna, turystyka zielona; pisano również o ekoturystyce (Szwichtenberg 1993). W pozycjach dotyczących tych zagadnień zwracano uwagę na zintegrowanie działalności turystycznej z celami ochrony przyrody oraz na kształtowanie nowych postaw i zachowań turystów oraz organizatorów ruchu turystycznego (Gołembski 2002).

Celem opracowania jest analiza strategii rozwoju agroturystyki w kontekście zrównoważonego rozwoju w gminach wiejskich i miejsko-wiejskich w powiatach nowotarskim oraz tatrzańskim.

\section{MATERIAŁ I METODY}

W powiatach nowotarskim i tatrzańskim zarejestrowano zdecydowanie najwięcej gospodarstw agroturystycznych w Małopolsce. Analizie poddano wszystkie gminne strategie obydwu powiatów pod względem ich mocnych (silnych) stron oraz szans w analizach SWOT w aspekcie rozwoju usług agroturystycznych. Ponadto przeprowadzono badania za pomocą kwestionariusza ankiety w urzędach gmin zlokalizowanych w tych powiatach. Łącznie poddano badaniom 17 gmin w obydwu powiatach; $\mathrm{z}$ każdej otrzymano wypełniony kwestionariusz. Badania wykonano jesienią 2015 roku. Ankietowanymi byli pracownicy urzędów gmin odpowiedzialni za promocję oraz rozwój turystyki. Kwestionariusz składał się zarówno z pytań otwartych, jak i zamkniętych. 


\section{ISTOTA TURYSTYKI ZRÓWNOWAŻONEJ}

Problemy zagrożenia środowiska przyrodniczego i potrzeba ich rozwiązywania stały się bardzo istotnym tematem wielu konferencji, kongresów na całym świecie już w latach 50. oraz 60. XX wieku. W 1972 roku na organizowanym w Sztokholmie I Szczycie Ziemi omawiano sposoby rozwiązywania problemów dotyczących zagrożeń dla środowiska na szczeblu ponadnarodowym. Wtedy po raz pierwszy użyto terminu „sustainable development”, czyli rozwoju zrównoważonego (Durydiwka i in. 2010). Jednak światowa ekspansja koncepcji rozwoju zrównoważonego rozpoczęła się od II Szczytu Ziemi, który odbył się w 1992 roku w Rio de Janeiro w Brazylii. Podczas tej konferencji podpisanych zostało kilka dokumentów, wśród których dla koncepcji rozwoju zrównoważonego istotne są Deklaracja z Rio, formułująca 27 zasad przyszłych praw i obowiązków, które mają doprowadzić do nowego ładu na Ziemi stanowiącego podstawę w dążeniu do osiągnięcia rozwoju zrównoważonego, a także AGENDA 21 (2010) zawierająca wytyczne dla jednostek terytorialnych różnego szczebla.

Pojęcie „rozwój zrównoważony” funkcjonuje od prawie pół wieku, jednak nadal nie sformułowano jego podstaw teoretycznych. Z praktycznego punktu widzenia jedną z istotniejszych kwestii są wskaźniki rozwoju zrównoważonego, które często się dzielone na trzy zasadnicze grupy (Fiedor 1999); są to:

- wskaźniki presji środowiskowej, czyli zagrożenia ( $P$ - ang. pressure), odnoszące się do tych form działalności, które zmniejszają ilość i pogarszają jakość zasobów środowiska;

- wskaźniki stanu środowiska, czyli jakości (S - ang. state), służące kwantyfikacji tych elementów środowiska, które mają bezpośredni wpływ na wielkość konsumpcji (dobrobyt materialny) i zdrowie;

- wskaźniki reakcji, czyli odpowiedzi społecznej na rozpoznane problemy środowiskowe ( $R$ - ang. response), pokazujące w jakim stopniu społeczeństwo jest skłonne zareagować na rosnącą presję środowiskową.

Koncepcja rozwoju zrównoważonego w przypadku turystyki dotyczy przede wszystkim określenia dopuszczalnego poziomu wzrostu ruchu turystycznego, który nie powodowałby negatywnych zmian w środowisku. Ma to istotne znaczenie dla jakości życia w przyszłości (Nijkamp i Verdonkschot 2000). Koncepcja turystyki zrównoważonej stanowiła reakcję na ekspansywny rozwój tzw. turystyki masowej (ang. mass tourism) i jej negatywny wpływ na środowisko przyrodnicze, a także społeczno-kulturowe w regionach recepcji turystycznej. Początkowo była ona nazywa turystyką alternatywną (ang. alternative tourism), turystyką łagodną (ang. soft tourism) oraz turystyką przyjazną środowisku (ang. environmentally sensible tourism) - Krippendorf (1986).

Podstawą koncepcji turystyki zrównoważonej była niewątpliwie definicja tzw. turystyki odpowiedzialnej (ang. responsible tourism), sformułowana w 1965 roku przez W. Hetzera, która oparta była na czterech filarach (Blamey 2001):

- na minimalizacji ingerencji w środowisko przyrodnicze,

- na poszanowaniu odmienności kulturowej,

- na maksymalizacji udziału ludności miejscowej w usługach turystycznych,

- na wzroście satysfakcji i zadowolenia z turystyki. 


\section{STRATEGIE ROZWOJU AGROTURYSTYKI W LITERATURZE}

Agroturystyka to forma turystyki wiejskiej dotycząca organizacji pobytu turystów w obrębie czynnych gospodarstw rolnych. Jednym z najważniejszych czynników rozwoju usług agroturystycznych są obszary cenne przyrodniczo, stanowiące najczęściej główny powód przyjazdu na wieś turystów mieszkających w miastach. Kontakt z czystym środowiskiem, brak hałasu, zanieczyszczeń, obszary pojezierne, górskie to istotne uwarunkowania rozwoju agroturystyki.

Ważnym czynnikiem rozwoju turystyki na obszarach wiejskich, w tym agroturystyki, jest realizacja różnych przedsięwzięć i działań zapisanych w strategiach rozwoju gmin. Dotyczą one często marketingu, kształtowania ofert agroturystycznych i intensyfikacji działań promocyjnych. Związane są także z urozmaiceniem usług rekreacyjnych świadczonych przez rolników oraz rekreacji możliwej do podejmowania przez turystów na wsi, w gminie, gdzie dane gospodarstwa agroturystyczne funkcjonują. Dotyczy to m.in. organizacji kuligów, przejazdów bryczką, jazdy konnej w terenie, wędrówek pieszych, wycieczek rowerowych.

Kilkanaście lat temu, tuż przed przystąpieniem Polski do Unii Europejskiej, Bieńkowska (2003) w swojej publikacji naukowej wskazała cztery modele strategii rozwoju agroturystyki w gminie (Różnice między nimi wynikały z wielkości i różnorodności ofert agroturystycznych):

1. Strategia penetracji rynku, która zakłada rozpoznanie rynku za pomocą obecnych na nim produktów. Cechuje się małym ryzykiem, ponieważ dotyczy nie nowego, tzw. wzbogaconego, produktu agroturystycznego, a jedynie usług podstawowych - noclegowych oraz niekiedy gastronomicznych.

2. Strategia rozszerzania, która polega na poszukiwaniu nowych rynków dla „starych produktów". Oprócz oferowania usług noclegowo-gastronomicznych w gospodarstwie agroturystycznym, szukając nowych nabywców, rolnicy powinni promować swoje usługi i sprzedawać je dodatkowo przez kanały pośrednie dystrybucji, np. w biurze turystycznym.

3. Strategia rozwoju produktu, która polega na rozszerzeniu obecnego już na znanych rynkach produktu, ale z zamiarem rozszerzenia go o dodatkowe jeszcze usługi, np. jazdę konną.

4. Strategia zróżnicowania - innowacji, która jest najbardziej ryzykowna, ma za pomocą nowych produktów otworzyć nowe rynki. Podczas realizacji tej strategii należy jednak pamiętać o tym, że innowacja w turystyce to rzecz niezbędna.

W praktyce w strategiach rozwoju gmin wiejskich i miejsko-wiejskich, jeśli są zapisane w analizach SWOT działania wspierające agroturystykę, to wyżej wymienione nazwy strategii agroturystyki samodzielnie nie występują. Oczywiście, pisano nierzadko w ramach silnych (mocnych) stron analizy SWOT o zróżnicowanej ofercie agroturystycznej, o różnych usługach rekreacyjnych, co odnosi się całkowicie do przedstawionej jako trzeciej strategii rozwoju produktu agroturystycznego. Nie stosuje się natomiast w tym zakresie nazwy „strategia rozwoju produktu agroturystycznego". Podobnie jest z czwartą strategią prezentowaną przez Bieńkowską (2003) - ze strategią zróżnicowania - innowacji, która ma na celu dotarcie do nowych rynków, do kolejnych grup turystów. Można polemizować z autorką nt. sposobu realizacji tej strategii, zastanawiając się, jak można zachęcić nowe grupy turystów do przyjazdu na wypoczynek do gospodarstw agroturystycznych w danej gminie. Jeśli chodziłoby np. o pielgrzymów, byłoby to możliwe w sytuacji istnienia w gminie lub 
w najbliższym regionie jakiegoś sanktuarium lub znanego obiektu sakralnego. Jeśli w strategii zapisana byłaby grupa turystów niepełnosprawnych i ich opiekunów, to część gospodarstw agroturystycznych w gminie musiałaby wprowadzić w budynku oraz w jego otoczeniu odpowiednie udogodnienia dla tego segmentu rynku. W przypadku natomiast uruchomienia w niedużej odległości od gospodarstw agroturystycznych wyciągu narciarskiego można byłoby promować ofertę agroturystyczną do miłośników sportów zimowych, głównie narciarzy.

W analizach SWOT strategii rozwoju wielu gmin wiejskich oraz miejsko-wiejskich w Polsce najczęściej wymienia się w mocnych stronach gminy oraz w jej szansach rozwoju przyrodnicze, kulturowe, ekonomiczne oraz społeczne czynniki determinujące rozwój agroturystyki. W ramach tych pierwszych bardzo często pisano o walorach środowiska przyrodniczego, np. o górach, jeziorach, rzekach, lasach, a także o dobrach kulturowych, przeważnie o zabytkach architektury, zabytkowych kościołach i kaplicach, dworach, muzeach, skansenach czy o bogatym folklorze i dziedzictwie kulturowo-historycznym. Zwracano ponadto uwagę w silnych stronach gminy na zróżnicowaną ofertę agroturystyczną. Z kolei w szansach rozwoju tej formy turystyki wiejskiej zauważa się często modę na wypoczynek mieszkańców miast na wsi w gospodarstwach agroturystycznych oraz możliwość rozwoju agroturystyki dzięki jej wsparciu przez działania i środki pochodzące z Unii Europejskiej.

W okresie, w którym cytowana już kilkakrotnie Bieńkowska (2003) zaprezentowała powyższe strategie rozwoju usług agroturystycznych, rolnicy chcący założyć gospodarstwo agroturystyczne mogli ubiegać się o wsparcie na ten cel z przedakcesyjnego programu SAPARD. Z działania $\mathrm{nr} 4$ tego programu, o nazwie „Różnicowanie działalności gospodarczej na obszarach wiejskich”, wynika, że w jego schemacie 4.1. „Tworzenie źródeł dodatkowego dochodu w gospodarstwach rolnych" była możliwość uzyskania refundacji do $50 \%$ całkowitych kosztów kwalifikowanych, czyli poczynionych inwestycji na przygotowanie pokoi dla turystów, zakup mebli, łóżek, modernizację pomieszczeń wspólnych, altanek, mebli ogrodowych, itd. Wysokość pomocy finansowej ze schematu 4.1 nie mogła w tym okresie przekroczyć 40 tys. zł.

Przed wejściem Polski do UE i ówczesnymi możliwościami wsparcia rozwoju usług agroturystycznych z programu SAPARD na rolę agroturystyki w społeczno-gospodarczym rozwoju obszarów wiejskich zwracała uwagę Krupińska (2003). Według niej agroturystyka może być szansą rozwoju wielu gmin wiejskich i miejsko-wiejskich w Polsce. Wskazywała na dywersyfikację lokalnej gospodarki na wsi dzięki rozwojowi turystyki wiejskiej i agroturystyki, równocześnie zaznaczając, że jest to proces bardzo złożony i wielowątkowy (Krupińska 2003).

Po przystąpieniu Polski do UE w całym kraju zaczęły powstawać nowe strategie rozwoju gmin. Ponownie w wielu przypadkach w strategiach zamieszczane były różne działania wspierające rozwój usług agroturystycznych. Dotyczyły one przeważnie gmin położonych w regionach pojeziernych, górskich, otulinach parków krajobrazowych i narodowych. W analizach SWOT pisano często o dużym potencjale turystycznym regionu, o atrakcyjnych walorach krajobrazowych i kulturowych, o modzie na agroturystykę i o zróżnicowanych ofertach rekreacyjnych. Należy stwierdzić, iż strategia rozwoju turystyki, w tym agroturystyki 
w gminach wiejskich i niekiedy miejsko-wiejskich, jest istotnym narzędziem zarządzania lokalną gospodarką turystyczną. Ponieważ strategia ta wymaga perspektywicznego i długookresowego planu działania (Michałowski i Ziółkowski 2002), proces jej formułowania powinien skupić się na wyborze najważniejszych i najpilniejszych celów oraz zadań realizacyjnych.

W wielu przypadkach rola turystyki wiejskiej i agroturystyki w strategii rozwoju gminy jest istotna. Szczególnie odnosi się to do obszarów charakteryzujących się wybitnymi walorami przyrodniczo-krajobrazowymi. Gminy te mają na swoim terenie jeziora, rzeki, kompleksy leśne oraz wytyczone szlaki turystyki pieszej i rowerowej będące klasycznymi przykładami walorów specjalistycznych. Wypoczywający w gospodarstwach agroturystycznych turyści mogą także zwiedzać zabytki architektury, muzea, skanseny, poznawać dziedzictwo kulturowo-historyczne i uczestniczyć w różnych imprezach kulturowych, np. w dożynkach, festynach czy odpustach.

Rozwój agroturystyki w gminie często uwarunkowany jest różnymi formami wsparcia władz lokalnych. Samorządy gminne mogą być podmiotem zarządzającym rozwojem lokalnych usług agroturystycznych w zakresie marketingu terytorialnego, a w szczególności we wspomnianej promocji agroturystyki.

\section{STRATEGIA ROZWOJU AGROTURYSTYKI W KONCEPCJI ROZWOJU ZRÓWNOWAŻONEGO}

Turystyka zrównoważona dotyczy wypoczynku turystów na obszarach cennych przyrodniczo. Związana jest głównie z terenami wiejskimi i odnosi się do różnych rodzajów turystyki wiejskiej. W przypadku koncepcji turystyki zrównoważonej na wsi najczęściej w literaturze pisano o ekoturystyce, agroturystyce, turystyce kulturowej i różnych formach turystyki kwalifikowanej.

Przed wejściem Polski do Unii Europejskiej na agroturystykę jako istotny element zrównoważonego rozwoju obszarów cennych przyrodniczo zwracał uwagę Jalinik (2002), który podkreślał jej rolę w przyjaznym stosunku turystów do środowiska przyrodniczego. Jalinik (2005) już po przystąpieniu Polski do UE pisał, że agroturystyka rozwija się głównie na bazie posiadanych zasobów (mieszkaniowych, krajobrazowych, rekreacyjnych i żywnościowych), walorów przyrodniczych w miejscowościach wiejskich oraz na podstawie niezdegradowanych jeszcze przez turystykę czysto komercyjną terenów. Według niego rozwój agroturystyki był wówczas, czyli kilkanaście lat temu, realizowany w myśl zasad zrównoważonego rozwoju środowiska. Uważa, że w różnych koncepcjach agroturystyki, nawiązujących bezpośrednio lub pośrednio do idei zrównoważonego rozwoju środowiska, na pierwszy plan wysuwają się następujące zasady:

- rozwój usług agroturystycznych powinien być dostosowany do rodzaju oraz jakości zasobów środowiska przyrodniczego i nie może przyczyniać się do ich degradacji;

- mieszkańcy obszarów wiejskich powinni partycypować w przedsięwzięciach dotyczących rozwoju agroturystyki, które podejmowane są na zamieszkałych przez nich obszarach;

- oferta agroturystyczna powinna być oparta na miejscowych i lokalnych zasobach ludzkich, materialnych oraz naturalnych; 
- rozwój agroturystyki powinien być zintegrowany z miejscowym rozwojem gospodarki, a także być korzystny pod względem etycznym, społecznym oraz ekonomicznym dla mieszkańców obszarów wiejskich.

W wydanej w 2009 roku książce „Agroturystyka w agrobiznesie” Damian Knecht pisał o dużym wpływie środowiska przyrodniczego na rozwój agroturystyki (2009). Inni autorzy również zwracali uwagę na istotną rolę walorów przyrodniczych w jej rozwoju (Wiatrak 1995; Bott-Alama 2005; Sznajder; Przezbórska 2006; Sikorska-Wolak 2009; Zawadka 2010; Przezbórska-Skobień 2015).

Knecht (2009) oprócz atrakcji przyrodniczych dostrzegał wśród uwarunkowań rozwoju usług agroturystycznych również dużą rolę władz lokalnych w gminie. Twierdził, iż ich zadaniem, przy wsparciu mieszkańców, jest eksponowanie walorów przyrodniczych terenu przez wyznaczanie i organizowanie punktów widokowych, szlaków spacerowych, ścieżek zdrowia i tras rowerowych. Podkreślał znaczenie rozwoju infrastruktury proekologicznej w gminie, np. poprzez budowę wodociągów, kanalizacji, oczyszczalni ścieków, bezpiecznych dla środowiska wysypisk śmieci czy obiektów uzdatniania wody. Ponadto wskazywał na inwestycje wspierające ekologiczne wzory turystyki, które powinny być zauważalne w dziedzinie transportu, wytwarzaniu energii, gospodarki odpadami, ściekami, wodą.

\section{STRATEGIA ROZWOJU AGROTURYSTYKI W WOJEWÓDZTWIE MAŁOPOLSKIM NA PRZYKŁADZIE POWIATÓW NOWOTARSKIEGO I TATRZAŃSKIEGO}

W 2014 roku w Polsce funkcjonowało 8016 gospodarstw agroturystycznych; najwięcej (1327) było zarejestrowanych w województwie małopolskim (Niedziółka 2017). W regionie tym było ich aż o 342 więcej aniżeli w uplasowanym na drugiej pozycji województwie podkarpackim (tab. 1).

Tabela 1. Liczba gospodarstw agroturystycznych w Polsce w 2014

\begin{tabular}{|l|c||l|c|}
\hline \multicolumn{1}{|c|}{ Województwo } & $\begin{array}{c}\text { Liczba gospodarstw } \\
\text { agroturystycznych }\end{array}$ & \multicolumn{1}{|c|}{ Województwo } & $\begin{array}{c}\text { Liczba gospodarstw } \\
\text { agroturystycznych }\end{array}$ \\
\hline dolnośląskie & 616 & podkarpackie & 985 \\
\hline kujawsko-pomorskie & 234 & podlaskie & 625 \\
\hline lubelskie & 456 & pomorskie & 672 \\
\hline lubuskie & 108 & śląskie & 404 \\
\hline łódzkie & 165 & świętokrzyskie & 313 \\
\hline małopolskie & 1327 & warmińsko-mazurskie & 801 \\
\hline mazowieckie & 364 & wielkopolskie & 438 \\
\hline opolskie & 119 & zachodniopomorskie & 389 \\
\hline
\end{tabular}

Źródło: Rolnictwo i gospodarka żywnościowa... (2015).

W województwie małopolskim w 2014 roku zdecydowanie najwięcej usług agroturystycznych świadczonych było w powiecie tatrzańskim (565) oraz w powiecie nowotarskim (552).

W powiecie nowotarskim w 2014 roku zdecydowanie najwięcej gospodarstw agroturystycznych funkcjonowało na terenie gminy Czorsztyn (180). Gmina Krościenko nad Dunajcem miała 93 tego typu obiekty, a w gminie Łapsze Niżne 93 rolników świadczyło dla turystów usługi agroturystyczne (tab. 2). 
Tabela 2. Liczba gospodarstw agroturystycznych w gminach powiatu nowotarskiego w 2014 roku

\begin{tabular}{|l|c|}
\hline \multicolumn{1}{|c|}{ Gmina } & $\begin{array}{c}\text { Liczba gospodarstw } \\
\text { agroturystycznych }\end{array}$ \\
\hline Czarny Dunajec & 54 \\
\hline Czorsztyn & 180 \\
\hline Jabłonka & 20 \\
\hline Krościenko nad Dunajcem & 93 \\
\hline Lipnica Wielka & 12 \\
\hline Łapsze Niżne & 72 \\
\hline Nowy Targ & 21 \\
\hline Ochotnica Dolna & 27 \\
\hline Raba Wyżna & 25 \\
\hline Rabka-Zdrój & 13 \\
\hline Spytkowice & 6 \\
\hline Szaflary & 21 \\
\hline Szczawnica & 8 \\
\hline Razam & 552 \\
\hline
\end{tabular}

Wszystkie gminy powiatu nowotarskiego mają opracowane strategie rozwoju, które nadal są aktualne. W każdej z nich zawarta została ocena szans i zagrożeń dla rozwoju różnych form turystyki. Ponadto w misjach i wizjach strategicznych gmin został ujęty rozwój usług turystycznych; oprócz jednej gminy Szczawnica w każdym dokumencie uwzględniono również rozwój agroturystyki.

W dokumentach strategicznych w mocnych stronach w analizie SWOT uwzględniono rolę walorów przyrodniczych w rozwoju turystyki wiejskiej i agroturystyki. Oprócz nich wymieniono również walory kulturowe, folklor oraz różnorodność usług rekreacyjnych. Te podstawowe dobra turystyczne stanowią podstawę rozwoju branży turystycznej na obszarach wiejskich i są ważnym czynnikiem turystyki zrównoważonej.

Na pytanie ankietowe o najczęściej uprawiane formy turystyki w gminie w odpowiedziach zdecydowanie dominowała turystyka kwalifikowana (specjalistyczna), a w jej obrębie: turystyka piesza, rowerowa, konna, narciarska i wodna, co jest bliskie koncepcji rozwoju zrównoważonego, ponieważ wspólną cechą tych rodzajów turystyki kwalifikowanej jest ich ścisły związek ze środowiskiem przyrodniczym. Wynika to z faktu, iż mogą być one uprawiane tylko na wolnym powietrzu i często na terenach, które w niewielkim stopniu zostały przekształcone przez działalność człowieka. Drugą ich cechą jest to, że pozytywnie oddziałują na miejscową gospodarkę, a zwłaszcza na lokalny rynek pracy (Jarzębowska i in. 2010). Na agroturystykę natomiast wskazano w trzech gminach: Czarny Dunajec, Lipnica Wielka i Szaflary. Wydaje się jednak, że ankietowani zaznaczali głównie formy spędzania czasu wolnego, w tym przeważnie wypoczynek aktywny, nie zwracając uwagi na rodzaj bazy noclegowej.

Różne przedsięwzięcia władz lokalnych i inwestycje są istotne w rozwoju turystyki zrównoważonej w gminie. Dotyczy to oczywiście również rozwoju usług agroturystycznych. Dlatego kolejne pytanie zawarte w kwestionariuszu ankiety dotyczyło przedsięwzięć wspierających turystykę, w tym ze środków zewnętrznych w latach 2007-2013, czyli w okresie realizacji programu rozwoju obszarów wiejskich (PROW). Ankietowani wskazywali na rodzaje inwestycji oraz na źródła ich finansowania (tab. 3). 
Tabela 3. Finansowanie przedsięwzięć turystyczno-rekreacyjnych w gminach powiatu nowotarskiego ze środków zewnętrznych w latach 2008-2013

\begin{tabular}{|c|c|c|}
\hline Gmina & Rodzaj wsparcia & Źródło finansowania \\
\hline \multirow{3}{*}{ Czorsztyn } & $\begin{array}{l}\text { budowa placu rekreacyjnego z pasażem usługowo-handlowym } \\
\text { w Sromowcach Niżnych }\end{array}$ & $\begin{array}{l}\text { PROW „Odnowa } \\
\text { i rozwój wsi” }\end{array}$ \\
\hline & 1. Ścieżka przyrodniczo-leśna „Modrzewie” w Kluszkowcach & $\begin{array}{l}\text { małopolski regionalny } \\
\text { program operacyjny }\end{array}$ \\
\hline & 2. Ścieżka rekreacyjno-piesza wokół Pienińskiej Pętli & brak odpowiedzi \\
\hline $\begin{array}{l}\text { Krościenko } \\
\text { n/Dunajcem }\end{array}$ & $\begin{array}{l}\text { pozyskanie środków unijnych na rozwój infrastruktury turystycznej } \\
\text { (wykonano elektroniczną tablicę informacyjno-turystyczną, za- } \\
\text { montowano trzy infonety dla uatrakcyjnienia formy przekazu } \\
\text { informacji turystycznej, wybudowano place zabaw, wyremon- } \\
\text { towano źródła wód mineralnych) }\end{array}$ & PROW 2007-2013 \\
\hline Lipnica Wielka & $\begin{array}{l}\text { 1. Ścieżka rowerowa w Kiczarach } \\
\text { 2. Projekt realizacji ścieżki rowerowej w Przywarówce }\end{array}$ & $\begin{array}{l}\text { środki z Unii } \\
\text { Europejskiej }\end{array}$ \\
\hline Raba Wyżna & $\begin{array}{l}\text { 1. Marketing, promocja, przewodnik historyczno-kulturalny } \\
\text { 2. Współpraca z euroregionem Tatry } \\
\text { 3. Współpraca transgraniczna - Rzeczpospolita Polska i Repu- } \\
\text { blika Słowacka }\end{array}$ & $\begin{array}{l}\text { Europejski Fundusz } \\
\text { Rozwoju Regionalnego } \\
\text { 2007-2013 }\end{array}$ \\
\hline Rabka-Zdrój & $\begin{array}{l}\text { m.in. rewitalizacja drewnianego budynku Lubogoszczy w Parku } \\
\text { Zdrojowym, rozbudowa szkoły w Ponicach, rozbudowa Parku } \\
\text { Zdrojowego (zob. Projekty unijne, www.rabka.pl) }\end{array}$ & brak odpowiedzi \\
\hline Szczawnica & promenada & $\begin{array}{l}\text { w ramach współpracy } \\
\text { transgranicznej }\end{array}$ \\
\hline
\end{tabular}

Z powyższej tabeli wynika, że większość inwestycji dotyczyła modernizacji infrastruktury turystycznej niezbędnej do rozwoju turystyki wiejskiej i agroturystyki. Źródła finansowania dotyczyły środków pochodzących z Unii Europejskiej.

Badania ankietowe, dotyczące strategii rozwoju agroturystyki, zrealizowano również w czterech gminach należących do powiatu tatrzańskiego, które także mają opracowane aktualne dokumenty strategiczne. Gmina Biały Dunajec ma strategię na lata 2014-2020, gmina Bukowina Tatrzańska - na lata 2015-2020, a gminy Kościelisko oraz Poronin - na lata 2016-2022. Dokumenty te poddano analizie, a dodatkowo przedstawiono wyniki badań ankietowych przeprowadzonych w gminach powiatu tatrzańskiego.

W powiecie tatrzańskim w roku 2014 funkcjonowało łącznie aż 565 gospodarstw agroturystycznych. Najwięcej rolników zajmowało się agroturystyką w gminie Bukowina Tatrzańska (190), a najmniej - w gminie Kościelisko (82) - tab. 4.

Podobnie jak w przypadku strategii gmin nowotarskich także strategie tatrzańskich gmin zawierają w swoich analizach SWOT szanse i zagrożenia dla rozwoju różnych form turystyki, w tym agroturystyki. Również w ich silnych stronach podano czynniki determinujące rozwój agroturystyki, a w misjach i wizjach strategicznych uwzględniono rozwój turystyki oraz usług agroturystycznych.

Tabela 4. Liczba gospodarstw agroturystycznych w gminach powiatu tatrzańskiego w 2014 roku

\begin{tabular}{|l|c|}
\hline \multicolumn{1}{|c|}{ Gmina } & $\begin{array}{c}\text { Liczba gospodarstw } \\
\text { agroturystycznych }\end{array}$ \\
\hline Biały Dunajec & 159 \\
\hline Bukowina Tatrzańska & 190 \\
\hline Kościelisko & 82 \\
\hline Poronin & 134 \\
\hline Razem & 565 \\
\hline
\end{tabular}

W każdym z czterech dokumentów strategicznych w mocnych stronach analizy SWOT można, tak samo jak w przypadku gmin nowotarskich, znaleźć zapis o dużej roli walorów przyrodniczych w rozwoju turystyki wiejskiej, w tym agroturystyki, również walorów 
kulturowych, folkloru jako kolejnych ważnych czynników determinujących rozwój usług turystyczno-rekreacyjnych na terenach wiejskich powiatu tatrzańskiego. Są to czynniki, które w dużym stopniu dotyczą koncepcji turystyki zrównoważonej.

W odpowiedzi na pytanie ankietowe o najczęściej uprawiane formy turystyki w gminie Bukowina Tatrzańska wskazano dwa rodzaje turystyki kwalifikowanej - narciarską i pieszą górską. W gminie Biały Dunajec badany wskazał narciarstwo zjazdowe oraz spacery. Z kolei w gminie Kościelisko otrzymano odpowiedź, że na jej terenie uprawia się turystykę pieszą i rowerową. Ankietowany w gminie Poronin stwierdził, że prym w gminie wiedzie turystyka narciarska.

W powiecie tatrzańskim, podobnie jak w przypadku gmin należących do powiatu nowotarskiego, w latach 2007-2013 zrealizowano różne inwestycje, które w rozwoju turystyki zrównoważonej w gminie mają bardzo istotne znaczenie. Część z nich była współfinansowana ze środków Unii Europejskiej. Tylko respondent w gminie Bukowina Tatrzańska nie udzielił odpowiedzi na pytanie o zrealizowane przedsięwzięcia inwestycyjne (tab. 5).

Tabela 5. Finansowanie przedsięwzięć turystyczno-rekreacyjnych w gminach powiatu tatrzańskiego ze środków zewnętrznych w latach 2008-2013

\begin{tabular}{|c|c|c|}
\hline Gmina & Rodzaj wsparcia & Źródło finansowania \\
\hline $\begin{array}{l}\text { Biały } \\
\text { Dunajec }\end{array}$ & szkolenia agroturystyczne & $\begin{array}{l}\text { budżet gminy bądź } \\
\text { środki z UE }\end{array}$ \\
\hline \multirow{3}{*}{ Kościelisko } & $\begin{array}{l}\text { 1. Boisko i chodnik we wsi Dzianisz } \\
\text { 2. Boisko w Witowie } \\
\text { 3. Estetyczne zagospodarowanie przestrzeni publicznej w Kościelisku }\end{array}$ & PROW 2007-2013 \\
\hline & 4. Powstanie Gminnego Ośrodka Kultury Regionalnej & $\begin{array}{l}\text { program współpra- } \\
\text { cy zagranicznej } \\
\text { Polska-Słowacja } \\
2007-2013\end{array}$ \\
\hline & 5. Modernizacja szlaku pieszo-rowerowego & euroregion Tatry \\
\hline Poronin & $\begin{array}{l}\text { 1. Promocja gminy } \\
\text { 2. Organizacja różnych imprez }\end{array}$ & brak odpowiedzi \\
\hline
\end{tabular}

Podobnie jak w przypadku przedsięwzięć inwestycyjnych w gminach należących do powiatu nowotarskiego w gminach tatrzańskich inwestycje dotyczyły również infrastruktury rekreacyjnej, z której mogą korzystać turyści. Także w źródłach finansowania na pierwszym miejscu znalazły się środki pochodzące $z$ działań unijnych.

\section{PODSUMOWANIE}

Południowa część województwa małopolskiego to bardzo atrakcyjny region turystyczny, W obrębie powiatów nowotarskiego i tatrzańskiego można uprawiać różne formy turystyki. Niezwykle ważna jest turystyka wiejska, a w jej obrębie agroturystyka, turystyka krajoznawcza, ekoturystyka, różne formy turystyki kwalifikowanej (piesza górska, rowerowa, narciarska, speleologiczna itd.), turystyka kulturowa.

W obydwu powiatach funkcjonują różne obiekty hotelarskie i noclegowe. Na ich wiejskich terenach oprócz kwater prywatnych dominują gospodarstwa agroturystyczne. Są to bardzo specyficzne obiekty świadczące usługi noclegowe, nierzadko także gastronomiczne, które są 
prowadzone przez rolników i ich rodziny. W gminach wiejskich powiatu tatrzańskiego (Biały Dunajec, Bukowina Tatrzańska, Kościelisko i Poronin) oraz w części gmin należących do powiatu nowotarskiego (Czorsztyn, Łapsze Niżne, Krościenko nad Dunajcem i Czarny Dunajec) było w roku 2014 zarejestrowanych od kilkudziesięciu do 180 (w gminie Czorsztyn) gospodarstw agroturystycznych.

W silnych (mocnych) stronach w analizach SWOT strategii gmin w powiatach nowotarskim i tatrzańskim zapisano wiele różnych czynników determinujących rozwój agroturystyki. Do najważniejszych zaliczono walory krajobrazowe, głównie obszary górskie, lasy, w przypadku gmin Czorsztyn i Łapsze Niżne - także Jezioro Czorsztyńskie. Pisano o walorach specjalistycznych, a więc tych cechach środowiska przyrodniczego, które umożliwiają rozwój różnych form turystyki kwalifikowanej (aktywnej), czyli o szlakach turystyki pieszej, rowerowej, niekiedy konnej; zamieszczono ponadto informacje o możliwości uprawiania sportów zimowych oraz wodnych.

Wśród zrealizowanych w obydwu powiatach przedsięwzięć inwestycyjnych w sektorze turystyczno-rekreacyjnym, ważnych dla rozwoju różnych form turystyki zrównoważonej, najwięcej było inwestycji mających na celu budowę albo modernizację infrastruktury rekreacyjno-turystycznej. W grupie tej można wyróżnić ścieżki piesze, rowerowe oraz budowę boisk. Ponadto inwestycje dotyczyły promocji i informacji turystycznej, a więc elementów marketingu, mających na celu przekazanie potencjalnym turystom informacji o walorach turystycznych gminy i o formach turystyki możliwych do uprawiania na jej terenie.

\section{PIŚMIENNICTWO}

Bieńkowska D. 2003. Instytucje i środki realizacji strategii gmin, w: Strategia rozwoju gmin wiejskich. Red. M. Kłodziński. Warszawa, Wydaw. SGGW, 143.

Blamey R.K. 2001. Principles of ecotourism, in: The encyklopedia of ecotourism. Red. D.B. Weaver. Oxon, CABI Publishing, 5-22.

Bott-Alama A. 2005. Uwarunkowania rozwoju turystyki wiejskiej w województwie zachodniopomorskim. Szczecin, Wydaw. Nauk. USzczec., 51.

Durydiwka M., Kowalczyk A., Kulczyk S. 2010. Definicja i zakres pojęcia „turystyka zrównoważona”, w: Turystyka zrównoważona. Red. A. Kowalczyk. Warszawa, Wydaw. Nauk. PWN, 24.

Fiedor B. 1999. Ogólny przegląd doświadczeń i koncepcji, w: Wskaźniki ekorozwoju. Red. T. Borys. Białystok, Wydaw. Ekonomia i Środowisko,150-160.

Gminny Program Rewitalizacji Gminy Łapsze Niżne na lata 2016-2023, https://www.lapszenizne.pl/ sites/default/files/pliki/2013/gpr_gminy_lapsze_nizne_na_lata_2016-2023_konsultacje_21.03.2017.pdf, dostęp: 30.08.2018.

Gołembski G. 2002. Pojęcie i cel zintegrowanego zarządzania jakością w regionach, w: Kompendium wiedzy o turystyce. Red. G. Gołembski. Warszawa, Wydaw. Nauk. PWN, 370.

Jalinik M. 2002. Agroturystyka na obszarach przyrodniczo cennych. Białystok, Wydaw. PBiałos.,13.

Jalinik M. 2005. Typologia gospodarstw agroturystycznych jako determinanta rozwoju usług. Białystok, Wydaw. PBiałos., 62, 63.

Jarzębowska M., Kowalczyk A., Kulczyk S., Kurkowska A., Lewandowski W. 2010. Turystyka kwalifikowana (turystyka aktywna) w koncepcji turystyki zrównoważonej, w: Turystyka zrównoważona. Red. A. Kowalczyk. Warszawa, Wydaw. Nauk. PWN, 256.

Kozłowski S. 1994. Droga do ekorozwoju. Warszawa, Wydaw. Nauk. PWN, 57.

Krippendorf J. 1986. Tourism in the system of industrial society. Ann. Tourism Res. 13(4), 517-532.

Knecht D. 2009. Agroturystyka w agrobiznesie. Warszawa, Wydaw. Nauk. C. H. Beck, 118. 
Krupińska W. 2003. Strategia rozwoju turystyki a proces kreowania nowych miejsc pracy na obszarach wiejskich, w: Aktywizacja wiejskich obszarów problemowych. Red. M. Kłodziński, W. Dzun. Warszawa, IRWiR, 113.

Leszczycki S., Domański R. 1992. Geografia Polski społeczno-ekonomiczna. Warszawa, Wydaw. Nauk. PWN, 138.

Michałowski K., Ziółkowski R. 2002. Zarządzanie turystyką. Białystok, Wydaw. PBiałos., 138.

Niedziółka A. 2017. Stan i czynniki rozwoju usług agroturystycznych w powiecie nowotarskim w perspektywie wsparcia agroturystyki z programów Unii Europejskiej w latach 2014-2020. Kraków, Wydaw. Stow. Nauk. Inst. Gosp. Rynku, 37.

Nijkamp P., Verdonkschot S. 2000. Sustainable tourism development: a case study of Lesbos, in: Sustainable tourism development. Red. H. Coccossis, P. Nijjamp, P. Ashgate. Aldershot Burlington, Singapore, Sydney, 127-140.

Przezbórska-Skobień L. 2015. Uwarunkowania rozwoju turystyki wiejskiej w Polsce, Poznań, Wydaw. Uniw. Przyr. Pozn., 136, 137.

Rolnictwo i gospodarka żywnościowa w Polsce. 2015. Warszawa, MRiRW, 106.

Sikorska-Wolak I. 2009. Kształtowanie funkcji turystycznych obszarów wiejskich - potrzeby i możliwości, w: Turystyczne funkcje obszarów wiejskich. Red. I. Sikorska-Wollak. Warszawa, Wydaw. SGGW, 23.

Strategia Rozwoju Gminy Biały Dunajec na lata 2014-2020. 2014. Czarny Dunajec, Urząd Gminy Czarny Dunajec.

Strategia Rozwoju Gminy Bukowina Tatrzańska na lata 2015-2020. 2015. Bukowina Tatrzańska, Urząd Gminy Bukowina Tatrzańska.

Strategia Rozwoju Gminy Czarny Dunajec na lata 2014-2020. 2013. Czarny Dunajec, Urząd Gminy Czarny Dunajec.

Strategia Rozwoju Gminy Czorsztyn na lata 2016-2022. 2016. Czorsztyn, Urząd Gminy Czorsztyn.

Strategia Rozwoju Gminy Jabłonka na lata 2015-2025. 2015. Jabłonka, Urząd Gminy Jabłonka.

Strategia Rozwoju Gminy Kościelisko na lata 2016-2022. 2016. Kościelisko, Urząd Gminy Kościelisko.

Strategia Rozwoju Gminy Krościenko nad Dunajcem na lata 2015-2020. 2015. Krościenko nad Dunajcem, Urząd Gminy Krościenko nad Dunajcem.

Strategia Rozwoju Gminy Lipnica Wielka na lata 2015-2020. 2015. Lipnica Wielka, Urząd Gminy Lipnica Wielka.

Strategia Rozwoju Gminy Nowy Targ na lata 2015-2022. 2015. Nowy Targ, Urząd Gminy Nowy Targ.

Strategia Rozwoju Gminy Ochotnica Dolna na lata 2015-2022. 2015. Ochotnica Dolna, Urząd Gminy Ochotnica Dolna.

Strategia Rozwoju Gminy Poronin na lata 2016-2022. 2015. Poronin, Urząd Gminy Poronin.

Strategia Rozwoju Społeczno-Gospodarczego Gminy Raba Wyżna na lata 201-2022. 2016. Raba Wyżna, Urząd Gminy Raba Wyżna.

Strategia Rozwoju Gminy Rabka Zdrój na lata 2014-2020. 2014. Rabka-Zdrój, Urząd Miasta i Gminy Rabka Zdrój.

Strategia Rozwoju Gminy Spytkowice na lata 2017-2026. 2017. Spytkowice, Urząd Gminy Spytkowice.

Strategia Rozwoju Gminy Szaflary na lata 2007-2017. 2007. Szaflary, Urząd Gminy Szaflary.

Strategia Rozwoju Społeczno-Gospodarczego Miasta i Gminy Szczawnica na lata 2015-2020. 2015. Szczawnica, Urząd Miasta i Gminy Szczawnica.

Sznajder M., Przezbórska L. 2006. Agroturystyka. Warszawa, Wydaw. PWE, 49.

Szwichtenberg A. 1993.Turystyka alternatywna i ekoturystyka - nowe pojęcia w geografii turyzmu. Turyzm 3(2), 51-59.

Wiatrak A.P. 1995. Agroturystyka jako forma zagospodarowania obszarów wiejskich, w: Restrukturyzacja funkcjonalno-przestrzenna obszarów wiejskich Polski, Toruń, Wydaw. UMK, 208. 
Zawadka J. 2010. Ekonomiczno-społeczne determinanty rozwoju agroturystyki na Lubelszczyźnie. Warszawa, Wydaw. SGGW, 94-95.

Streszczenie. W artykule przedstawiono kwestie dotyczące zrównoważonego rozwoju agroturystyki oraz strategii jej rozwoju. Opisano na podstawie literatury koncepcję rozwoju zrównoważonego oraz jego odniesienie do turystyki. Dokonano przeglądu pozycji książkowych oraz artykułów naukowych związanych z problematyką strategii rozwoju usług agroturystycznych $w$ kontekście rozwoju zrównoważonego. Przedstawiono tę problematykę na przykładzie strategii rozwoju gmin w dwóch powiatach województwa małopolskiego charakteryzujących się największą liczbą gospodarstw agroturystycznych - powiatu nowotarskiego i powiatu tatrzańskiego. Wykorzystano metodę badań dokumentów. Poddano analizie strategie gmin należących do tych powiatów. Zaprezentowano ponadto analizę wyników badań ankietowych przeprowadzonych w urzędach gmin. Badania te dotyczyły strategii rozwoju agroturystyki w gminie na zasadach rozwoju zrównoważonego. We wszystkich strategiach najważniejszymi czynnikami zrównoważonego rozwoju agroturystyki określono walory przyrodnicze. 
